\title{
PERTUMBUHAN TANAMAN KENARI (Canarium ambonensis) DI DEMPLOT SUMBER BENIH HATUSUA KABUPATEN SERAM BAGIAN BARAT
}

\author{
GROWTH OF WALNUTS PLANT (Canarium ambonensis) AT THE SEED SOURCE \\ DEMONSTRATION PLOT IN HATUSUA, WEST PART SERAM REGENCY \\ Oleh \\ Ludia Siahaya $^{1^{*}}$, C.M.A Wattimena ${ }^{2}$, dan Jacobs Harry $A^{3}$ \\ ${ }^{1,2,3}$ Jurusan Kehutanan, Fakultas Pertanian, Universitas Pattimura, Ambon, 97233 \\ Email : ledysiahaya@gmail.com \\ \begin{tabular}{|l|l}
\hline Diterima: 20 Juni 2020 & Disetujui:4 Juli 2020
\end{tabular}
}

\begin{abstract}
Abstrak
Penelitian ini bertujuan untuk mengetahui tingkat pertumbuhan riap tinggi dan riap diameter pada tanaman Kenari (Canarium ambonensis) selama 3.5 tahun pasca penanaman, mengetahui hubungan antara $\mathrm{pH}$ dengan Riap pertumbuhan tanaman Kenari (C. ambonensis), dan mengetahui hubungan antara kelembaban tanah dengan Riap pertumbuhan tanaman Kenari $(C$. ambonensis). Metode yang digunakan adalah metode observasi dan pengukuran tinggi, diameter, $\mathrm{pH}$ dan kelembaban tanah pada 100 individu tanaman Kenari. Setelah itu dihitung nilai riap tahunan berjalan atau CAI, riap rata-rata tahunan atau MAI dan regresi sederhana untuk melihat hubungan antara $\mathrm{pH}$ dan kelembaban tanah terhadap pertumbuhan tanaman Kenari. Hasil penelitian menunjukkan bahwa nilai CAI diameter 2,26 cm/tanaman/tahun dan MAI 1,41 cm/tanaman/tahun, sedangkan nilai CAI tinggi 1,72 m/tanaman/tahun dan MAI 0,97 $\mathrm{m} / \mathrm{tanaman} / \mathrm{tahun}$. Hubungan $\mathrm{pH}$ tanah dan kelembaban dengan riap pertumbuhan tanaman Kenari (Canarium ambonensis) memberikan kontribusi sangat rendah.
\end{abstract}

Kata kunci: Riap Pertumbuhan, Demplot, Sumber Benih

\begin{abstract}
The aim of this research was to know the level of growth of high and diameter increament of Kenari plant (Canarium ambonensis) for 3.5 years after planting, to know the relationship between $\mathrm{pH}$ and Kenari plant growth (C. ambonensis), and to know the relationship between soil moisture with Kenari plant growth (C. ambonensis). Method used was observation and measurement high, diameter, $\mathrm{pH}$ and moisture of soil at 100 of Kenari plant. Then, acoounting Current Annual Increatmnet (CAI), Mean Annual Increatmnet (MAI) value and Simple Regretion to show correlation between $\mathrm{pH}$ and moisture of soil with growth of Kenari plant. The results of the study showed value of diameter CAI and MAI were $2.26 \mathrm{~cm} /$ plant/year and 1.41 $\mathrm{cm} /$ plant/year, and value of high CAI and MAI were $1.72 \mathrm{~m} /$ plant/year and $0.97 \mathrm{~m} /$ plant/year. The relationship of soil $\mathrm{pH}$ and humidity with the growth of Kenari (Canarium ambonensis) can contribute very low.
\end{abstract}

Keywords: Growth Increament, Demplot, Seed Source

DOI: $10.30598 /$ jhppk.2020.4.2.184

ISSN ONLINE: 2621-8798 


\section{PENDAHULUAN}

Salah satu kebijakan Kementrian Kehutanan yang telah diimplementasikan dalam tiga dekade terakhir ini adalah rehabilitasi hutan dan lahan, dengan kegiatan utama penanaman. Salah satu kendala klasik dalam program penanaman (pembangunan dan pengembangan hutan) adalah belum tersedianya benih dalam jumlah yang cukup serta kualitas mutu benih yang masih rendah secara genetik. Guna diperoleh jaminan kinerja pertumbuhan yang baik dalam pembangunan hutan tanaman maka selain pemilihan jenis yang tepat, penggunaan bibit yang bermutu secara genetik juga sangat menentukan dalam program penanaman. Penyediaan bibit bermutu sangat terkait erat dengan status sumber benih yang tersedia pada saat ini. Sehubungan dengan hal tersebut, maka pembangunan sumber benih jenis-jenis pohon komersial menjadi suatu hal yang perlu diprioritaskan. Selain diharapkan dapat memenuhi kebutuhan benih bermutu secara genetik, melalui pembangunan kebun benih diharapkan dapat dilakukan peningkatan riap pertumbuhan dan produktivitas hutan tanaman yang akan dibangun, seperti hanya untuk tanama Kenari (Canarium ambonensis) (Sofyan, A. dkk.2012).

Tanaman Kenari (C. ambonensis) merupakan salah satu dari family Burseraceae yang termasuk tanaman MPTS (Multi Purpose Tree Species) dari Maluku yang mempunyai manfaat sangat banyak terutama dalam makanan Maluku. Dalam buah Kenari terdapat biji yang rasanya sangat enak, bisa langsung dimakan atau diolah menjadi minyak untuk obat-obatan karena memiliki kandungan minyak dan gizi diantaranya yaitu vitamin E, Selenium, Zinc, Zat Besi, Asam Lemak, Omega 3, Mangan, Triptofan, dan Tembaga. Selama ini biji
Kenari dimanfaatkan untuk bahan pangan camilan (makanan ringan) yang memiliki nilai potensi komersial misalnya halua Kenari, ditambah dalam pembuatan roti, kue, dan klarpert tart. Makanan yang mengandung biji Kenari tersebut menjadi makanan khas daerah sebagai oleh-oleh yang digemari oleh wisatawan. Karena kontribusi protein dan lemaknya membuat kedua komponen tersebut memberikan rasa gurih pada makanan. Oleh sebab itu Kenari menjadi produk pangan yang mempunyai nilai ekonomis tinggi, namun budidaya tanaman Kenari di daerah Maluku kurang diminati karena Kenari banyak tumbuh di hutan alam, sehingga masyarakat setempat lebih memilih untuk mengambil buah Kenari dari hutan alam dari pada membudidayakan tanaman Kenari.

Dengan melihat banyaknya manfaat Kenari yang berniali ekonomis tinggi, maka tanaman Kenari harus dibudidayakan. Oleh karena itu, maka dilakukan penanaman tanaman Kenari di Demplot Sumber Benih Hatusua. Untuk mengetahui pertumbuhannya, maka dilakukan penelitian dengan judul "Studi Pertumbuhan Tanaman Kenari (Canarium Ambonensis) Di Demplot Sumber Benih Desa Hatusua Kecamatan Kairatu Kabupaten Seram Bagian Barat." Adapun tujuan dalam penelitian ini antara lain:

1. Mengetahui riap tahunan (CAI) dan MAI diameter dan tinggi tanaman Kenari (C. ambonensis)?

2. Mengetahui hubungan antara $\mathrm{pH}$ dengan riap pertumbuhan tanaman Kenari $(C$. ambonensis).

3. Mengetahui hubungan antara kelembaban tanah dengan riap pertumbuhan tanaman Kenari $(C$. ambonensis). 


\section{METODE PENELITIAN}

Penelitian berlokasi di demplot sumber benih yang dibangun oleh BPTH (Balai Perbenihan Tanaman Hutan) Maluku dan Papua di Desa Hatusua Kecamatan Kairatu Kabupaten Seram Bagian Barat yang penanaman pertamanya dilakukan pada tangga 13 Januari 2013. Data awal yang diambil bulan Januari 2013 - Juli 2016 dan dilanjutkan dengan pengukuran setiap 6 bulan sampai Juli 2017. Peralatan yang digunakan, yaitu Hagameter, Jangka Sorong, Soiltester, Microsoftware Excel untuk analisis data, Lux meter, dan Thermometer Maximum-minimum. Bahan yang dipergunakan adalah label, tali tukang, cat merah, dan talysheet. Objek yang diamati pada penelitian ini adalah tanaman kenari (Canarim ambonensis) pada petak contoh blok I di demplot sumber benih yang berlokasi di Desa Hatusua Kecamatan Kairatu Kabupaten Seram Bagian Barat.

Metode yang digunakan dalam penelitian ini adalah metode deskriptif dengan teknik observari di lapangan. Teknik pengambilan contoh yang dikerjakan pada penelitian ini berupa pengamatan langsung

\section{MAI diameter}

$$
=\frac{D(\mathrm{~cm})}{\operatorname{Umur}(\text { tahun })}=
$$

$$
\frac{T(m)}{\operatorname{Umur}(\text { tahun })}
$$

dimana:

$$
\begin{aligned}
& \text { MAI : Riap rata-rata } \\
& \text { tahunan } \\
& \mathrm{D} \quad \text { : Diameter }(\mathrm{cm}) \\
& \mathrm{T} \quad \text { : Tinggi }(\mathrm{m})
\end{aligned}
$$

2. Riap Tahunan Berjalan (Current Annual Increment / CAI ) dilakukan khusus pada petak contoh blok I Kenari (Canarium ambonensis). Luasan petak pada areal blok I adalah $2 \mathrm{Ha}$ dengan jarak tanam $3 \mathrm{~m}$ x $3 \mathrm{~m}$, dimana Jumlah keseluruhan tanaman Kenari 100 pohon yang diambil berdasarkan penelitian sebelumnya. Teknik pengumpulan data didapat dari data primer yang diperoleh dari hasil pengamatan langsung terhadap objek penelitian (tinggi, diameter, $\mathrm{pH}$ tanah, kelembabab tanah, intensitas cahaya, kelembaban udarah dan suhu udara) dan data sekunder merupakan data pendukung yang diperoleh langsung dari pihak lain yaitu instansi pemerintah atau desa yang terkait untuk melengkapi serta mendukung penelitian ini data yang dibutuhkan data curah hujan selama tiga tahun dari BMKG Kabupaten Seram Bagian Barat.

Analisis data yang digunakan yaitu analisis kuantitatif dengan metode sebagai berikut :

1. Riap rata-rata tahunan (Mean Annual Increment / MAI ).

Menghitung riap rata-rata tahunan berdasarkan rumus Marsono (1987) sebagai berikut:

Menghitung riap tahunan berjalan berdasarkan rumus Marsono (1987) sebagai berikut:

$$
\begin{aligned}
& \text { CAI diameter }= \\
& \frac{D_{n+1}-D n}{T_{n+1}-T n}=\frac{\Delta D}{\Delta T} \\
& \text { CAI tinggi } \\
& \frac{H_{n+1}-H n}{T_{n+1}-T n}=\frac{\Delta H}{\Delta T}
\end{aligned}=
$$

dimana:

CAI : Riap Tahun Berjalan

$\mathrm{D}_{\mathrm{n}} \quad$ : Diameter tahun kemarin $(\mathrm{cm})$

$\mathrm{H}_{\mathrm{n}} \quad$ : Tinggi tahun kemarin $(\mathrm{m})$ 
$\mathrm{T}_{\mathrm{n}} \quad$ : Umur tahun

kemarin (thn)

$\frac{\Delta D}{\Delta T} \quad$ : Hasil perhitungan

riap diameter tahun

berjalan $(\mathrm{cm} / \mathrm{thn})$

3. Regresi Linier Sederhana

Regresi linier yang digunakan pada penelitian ini adalah analisis regresi linier sederhana dengan persamaan umum:

$$
\begin{aligned}
& \mathrm{Y}=\mathrm{a}+\mathrm{bX} \\
& \mathrm{Y}=\text { Riap pertumbuhan }
\end{aligned}
$$

tanaman Kenari (Canarium ambonensis)

$\mathrm{X}=\mathrm{pH}$ tanah dan

kelembaban

$\mathrm{a}=$ Konstanta

$\mathrm{b}=$ Koefisien regresi

Dengan hipotesis yang digunakan:

\section{HASIL DAN PEMBAHASAN}

\section{Riap Diameter Tanaman}

Hasil penelitian pertambahan diameter pada tanaman kenari (Canarium
$\frac{\Delta H}{\Delta T} \quad$ : Hasil perhitungan riap tinggi tahun berjalan $(\mathrm{m} / \mathrm{thn})$

$\mathrm{H}_{0}$ : Hubungan $\mathrm{pH}$ dan kelembaban tanah tidak berbeda nyata dengan riap pertumbuhan tanaman Kenari

$\mathrm{H}_{1}$ : Hubungan $\mathrm{pH}$ dan kelembaban tanah berbeda nyata dengan riap pertumbuhan

tanaman Kenari

$\mathrm{H}_{0} \quad$ diterima jika $\mathrm{F}$ hitung $<$ F tabel

$\mathrm{H}_{0}$ ditolak jika $\mathrm{F}$ hitung $>\mathrm{F}$ tabel

$\mathrm{F}$ tabel menggunakan tingkat kepercayaan 0.05 dan 0.1

ambonensis) tiap 6 bulan dari 3.5 tahun 4.5 tahun dapat dilihat pada Tabel 1

Tabel 1. Data Pertambahan Diameter untuk Pertumbuhan Tanaman Kenari (Canarium ambonensis) pada Tiap Pengukuran

\begin{tabular}{llllll}
\hline & \multicolumn{2}{l}{ Pengukuran Tanaman ke-... $(\mathrm{cm})$} & $\begin{array}{l}\text { Riap } \\
(\mathrm{cm})\end{array}$ & Diameter & Tanaman \\
\cline { 2 - 6 } & 8 & 9 & 10 & 9 & 10 \\
$\begin{array}{l}\text { Umur } \\
\text { Tanaman }\end{array}$ & 3.5 & 4 & 4.5 & 4 & 4.5 \\
$\begin{array}{l}\text { Waktu } \\
\text { Pengukuran }\end{array}$ & Jul-16 & Jan-17 & Jul-17 & Jan-17 & Jul-17 \\
Rata-Rata & 4.46 & 5.64 & 7.89 & 2.35 & 4.51 \\
Maximum & 6.72 & 9.08 & 11.60 & 5.72 & 7.18 \\
Minimum & 2.63 & 3.53 & 4.69 & 0.34 & 1.14 \\
\hline
\end{tabular}

Sumber : Data Penelitian 2017

Pada Tabel 1 terlihat bahwa diameter tanaman terbesar pada tahun terakhir berkisar $6.72 \mathrm{~cm} / 6$ bulan sampai $11.60 \mathrm{~cm} / 6$ bulan dan diameter terkecil berkisar $2.63 \mathrm{~cm} / 6$ bulan sampai $4.69 \mathrm{~cm} / 6$ bulan. Rata-rata pertambahan diameter mengalami peningkatan tiap 6 bulan yaitu pada Juli 2016 -Januari 2017 dengan rata-rata $2.35 \mathrm{~cm} / 6$ bulan sampai $4.51 \mathrm{~cm} / 6$ bulan dengan riap diameter terbesar yaitu $5.72 \mathrm{~cm} / 6$ bulan sampai $7.18 \mathrm{~cm} / 6$ bulan dan riap diameter terkecil dari $0.34 \mathrm{~cm} / 6$ bulan sampai 1.14 $\mathrm{cm} / 6$ bulan.

Berdasarkan Gambar 1 di bawah ini, riap diameter mengalami pertambahan. Seperti yang dijelaskan oleh David and 
Jhonson (1987) bahwa pertumbuhan didefenisikan sebagai pertambahan dari jumlah dan dimensi pohon, baik diameter maupun tinggi yang terdapat satu tegakan dan terjadi karena aktivitas meristem primer, sedangkan pertumbuhan diameter terjadi karena aktivitas meristem sekunder atau kambium yang menghasilkan kulit dan kayu baru diantara kulit dan kayu lama.

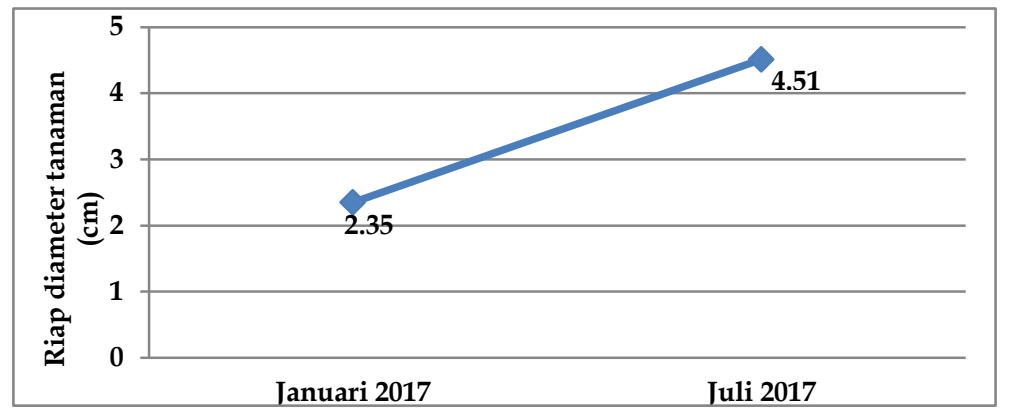

Gambar 1. Riap Diameter Tanaman Kenari (Canarium ambonensis) per 6 bulan

Riap Tahun Berjalan (CAI) dan RataRata Tahunan (MAI) Diameter pada Tanaman Kenari (Canarium ambonensis) semua pengukuran, maka diperoleh rata-rata perhitungan CAI dan MAI pada tahun keempat seperti pada Tabel 2 di bawah ini:

Pada hasil perhitungan CAI dan MAI

yang telah dibuat dari hasil rekapitulasi

Tabel 2 Riap Tahun Berjalan (CAI) dan Rata-Rata Tahunan (MAI) Diameter pada Tanaman Kenari (Canarium ambonensis)

\begin{tabular}{lccc}
\hline \multicolumn{3}{c}{ Pengukuran Tahun Kempat } \\
\hline & $\begin{array}{c}\text { Rata-Rata Pertumbuhan } \\
\text { Diameter }(\mathrm{cm})\end{array}$ & CAI $(\mathrm{cm})$ & MAI $(\mathrm{cm})$ \\
Rata-Rata & 5.64 & & 1.41 \\
Maximum & 9.08 & 2.26 & 2.27 \\
Minimum & 3.53 & 4.06 & 0.88 \\
\hline
\end{tabular}

Sumber : Data Penelitian 2017

Dari Tabel 2 dapat dilihat bahwa,

Sedangkan besar nilai rata-rata MAI adalah rata-rata pertumbuhan diameter tanaman kenari (Canarium ambonensis) pada tahun keempat adalah $5.64 \mathrm{~cm}$ dengan nilai maksimum $9.08 \mathrm{~cm}$ dan nilai minimum 3.53 $\mathrm{cm}$. Besar nilai rata-rata CAI adalah 2.26 $\mathrm{cm} /$ tahun dengan nilai maksimum 4.06 $1.41 \mathrm{~cm} /$ tahun dengan nilai maksimum 2.27 $\mathrm{cm} /$ tahun dan nilai minimum $0.88 \mathrm{~cm} /$ tahun.

Riap Tahunan Berjalan (CAI) dan Riap Rata-Rata Tahunan (MAI) diameter Tanaman Kenari (Canarium ambonensis) selama 4 tahun dapat dilihat pada Gambar 2 


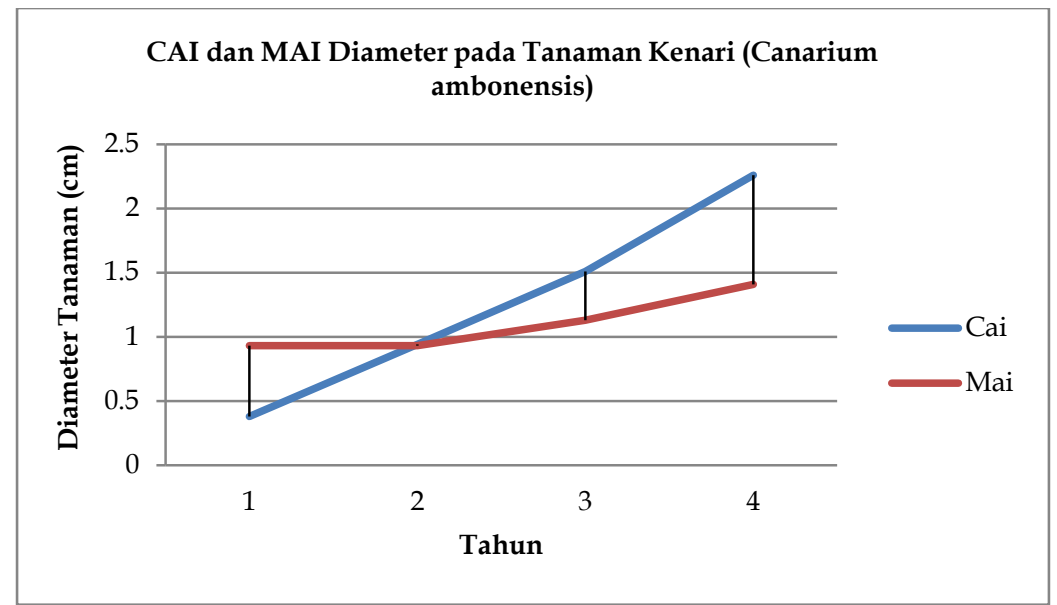

Gambar 2. Riap Tahun Berjalan (CAI) dan Rata-Rata Tahunan (MAI) Diameter Pada Tanaman Kenari (Canarium ambonensis)

Berdasarkan Gambar 2, terlihat bahwa riap tahunan berjalan (CAI) diameter tanaman pada tahun pertama lebih kecil dari riap rata-rata tahunan (MAI) yaitu 0.38 $(\mathrm{cm} / \mathrm{tnm} / \mathrm{thn})$ dan $0.93(\mathrm{~cm} / \mathrm{tnm} / \mathrm{thn})$. Pada tahun kedua, ketiga dan keempat riap tahunan berjalan (CAI) diameter tanaman lebih besar daripada riap rata-rata tahunan (MAI) diameter tanaman berturut-turut yaitu: 0.94 $(\mathrm{cm} / \mathrm{tnm} / \mathrm{thn})$ dan $0.93(\mathrm{~cm} / \mathrm{tnm} / \mathrm{thn}), 1.51$ $(\mathrm{cm} / \mathrm{tnm} / \mathrm{thn})$ dan $1.13(\mathrm{~cm} / \mathrm{tnm} / \mathrm{thn}), 2.26$ $(\mathrm{cm} / \mathrm{tnm} / \mathrm{thn})$ dan $1.41(\mathrm{~cm} / \mathrm{tnm} / \mathrm{thn})$. Riap rata-rata tahunan (MAI) pada tahun pertama dan kedua mempunyai nilai yang sama, menunjukkan bahwa riap rata-rata tahunan (MAI) tanaman kenari (Canarium ambonensis) tidak mengalami peningkatan, sebaliknya meningkat pada tahun ketiga dan keempat. Sehingga dapat dikatakan bahwa tanaman kenari (Canarium ambonensis) dapat tumbuh dengan baik dan beradaptasi dengan lingkungan hanya saja membutuhkan waktu agar pertumbuhan berjalan seoptimal mungkin karena didukung oleh faktor-faktor pendukung lain yang juga mempengaruhi.

tiap 6 bulan dari 3.5 tahun -4.5 tahun dapat dilihat pada Tabel 3

Hasil penelitian pertambahan tinggi pada tanaman kenari (Canarium ambonensis)

Tabel 3. Data Pertambahan Tinggi untuk Pertumbuhan Tanaman Kenari (Canarium ambonensis) pada Tiap pengukuran

\begin{tabular}{llllll}
\hline & \multicolumn{2}{l}{ Pengukuran Tanaman ke $(\mathrm{m})$} & & \multicolumn{2}{c}{ Riap Tinggi Tanaman $(\mathrm{m})$} \\
\cline { 2 - 6 } & 8 & 9 & 10 & 9 & 10 \\
$\begin{array}{l}\text { Umur } \\
\text { Tanaman }\end{array}$ & 3.5 & 4 & 4.5 & 4 & 4.5 \\
$\begin{array}{l}\text { Waktu } \\
\text { Pengukuran }\end{array}$ & Jul-16 & Jan-17 & Jul-17 & Jan-17 & Jul-17 \\
Rata-Rata & 2.71 & 3.86 & 5.48 & & \\
Maximum & 4.51 & 6.43 & 8.76 & 4.31 & 3.23 \\
Minimum & 1.60 & 2.64 & 4.02 & 0.54 & 7.88 \\
\hline
\end{tabular}

DOI: $10.30598 /$ jhppk.2020.4.2.184 
Pada Tabel 3 terlihat bahwa rata-rata tinggi tanaman berkisar $2.71 \mathrm{~cm} / 6$ bulan sampai $5.48 \mathrm{~cm} / 6$ bulan dengan tinggi terbesar $4.51 \mathrm{~cm} / 6$ bulan sampai $8.76 \mathrm{~cm} / 6$ bulan serta tinggi terendah berkisar $1.60 \mathrm{~cm} / 6$ bulan sampai $4.02 \mathrm{~cm} / 6$ bulan. Rata-rata pertambahan tinggi mengalami peningkatan tiap 6 bulan yaitu pada Juli 2016 - Januari 2017 dengan rata-rata $2.31 \mathrm{~cm} / 6$ bulan sampai $3.23 \mathrm{~cm} / 6$ bulan dengan riap tinggi terbesar yaitu $4.24 \mathrm{~cm} / 6$ bulan sampai 7.88 $\mathrm{cm} / 6$ bulan dan riap diameter terkecil dari $0.54 \mathrm{~cm} / 6$ bulan sampai $1.18 \mathrm{~cm} / 6$ bulan .

Berdasarkan Gambar 3 riap tinggi mengalami peningkatan. Terjadinya pertambahan tinggi karena pertumbuhan yang terjadi sebagai aktivitas meristem primer sehinggan batang bertambah panjang. Sel-sel berulang kali membelah diri menjadi sel baru. Sel baru yang dibentuk memperpanjang batang dan tunas tumbuh ke atas meninggalkan sel-sel baru yang kemudian bertumbuh makin besar.

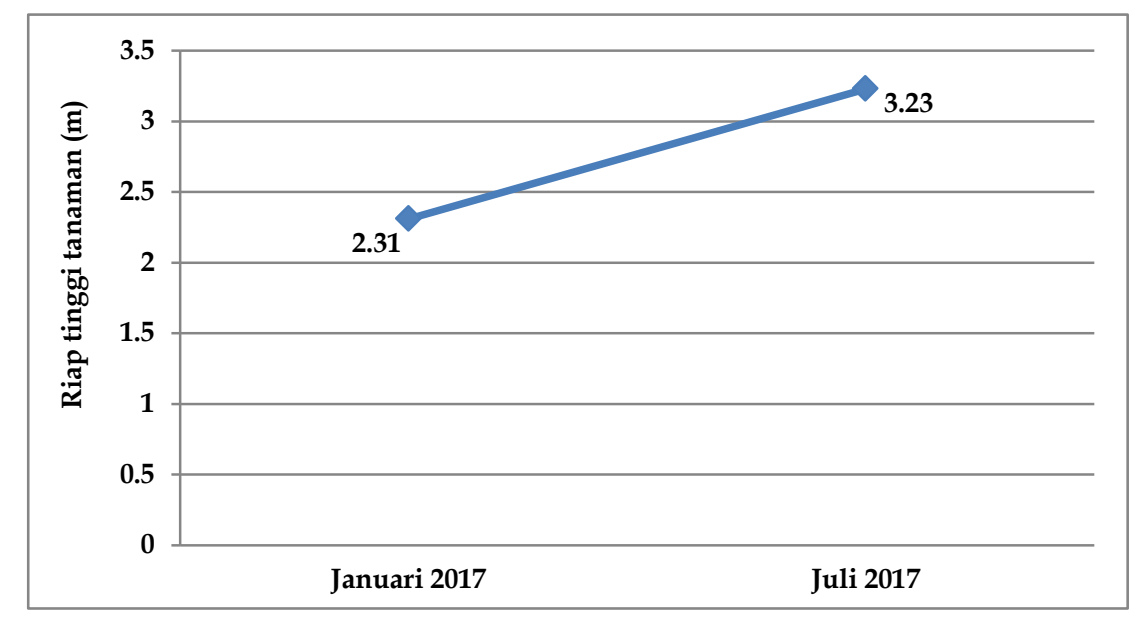

Gambar 3 Riap Tinggi Tanaman Kenari per 6 Bulan

Riap Tahun Berjalan (CAI) dan RataRata Tahunan (MAI) Tinggi pada Tanaman Kenari (Canarium ambonensis)

Pada hasil perhitungan CAI dan MAI semua pengukuran, maka diperoleh rata-rata perhitungan CAI dan MAI pada tahun keempat seperti pada Tabel 4 di bawah ini:

yang telah dibuat dari hasil rekapitulasi

Tabel 4 Riap Tahun Berjalan (CAI) dan Rata-Rata Tahunan (MAI) Tinggi pada Tanaman Kenari (Canarium ambonensis)

\begin{tabular}{cccc}
\hline \multicolumn{3}{c}{ Pengukuran Tahun Kempat } \\
\hline & $\begin{array}{c}\text { Rata-Rata Pertumbuhan } \\
\text { Tinggi (m) }\end{array}$ & CAI (m) & MAI (m) \\
Rata-Rata & 3.86 & 1.72 & 0.97 \\
Maximum & 6.43 & 2.82 & 1.61 \\
Minimum & 2.64 & 0.86 & 0.66 \\
\hline
\end{tabular}

Sumber : Data Penelitian 2017 
Dari Tabel 4 di atas, rata-rata pertumbuhan tinggi tanaman kenari (Canarium ambonensis) pada tahun keempat adalah $3.86 \mathrm{~m}$ dengan nilai maksimum 6.43 $\mathrm{m}$ dan nilai minimum $2.64 \mathrm{~m}$. Besar nilai rata-rata CAI adalah $1.72 \mathrm{~m} /$ tahun dengan nilai maksimum $2.82 \mathrm{~m} /$ tahun dan nilai minimum $0.86 \mathrm{~m} /$ tahun. Sedangkan besar nilai rata-rata MAI $0.97 \mathrm{~m} /$ tahun dengan nilai maksimum $1.61 \mathrm{~m} /$ tahun dan nilai minimum 0.66 m/tahun. Riap Tahunan Berjalan (CAI) dan Riap Rata-Rata Tahunan (MAI) tinggi tanaman kenari (Canarium ambonensis) selama 4 tahun dapat dilihat pada Gambar 4

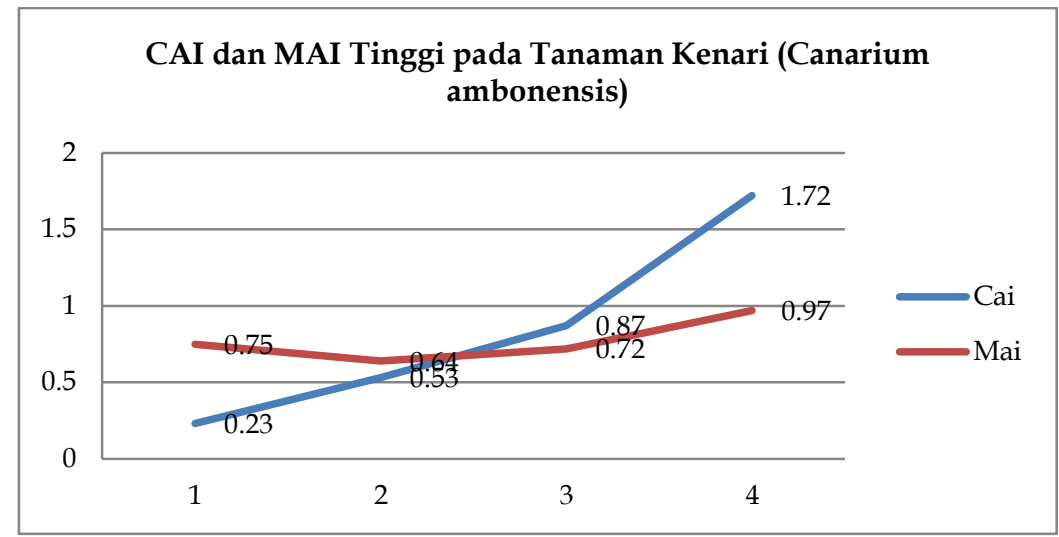

Gambar 4 Riap Tahun Berjalan (CAI) dan Rata-Rata Tahunan (MAI) Diameter Pada Tanaman Kenari (Canarium ambonensis)

Berdasarkan grafik pada Gambar 4, terlihat bahwa riap tahunan berjalan (CAI) tinggi tanaman lebih kecil nilainya dari riap rata-rata tahunan (MAI) tinggi tanaman dengan nilai $0.23 \mathrm{~m} /$ tahun dan $0.75 \mathrm{~m} /$ tahun.

Pada tahun kedua, ketiga dan keempat, riap tahunan berjalan (CAI) tinggi tanaman lebih besar daripada riap rata-rata tahunan (MAI) tinggi tanaman berturut-turut $0.64 \mathrm{~m} /$ tahun dan $0.53 \mathrm{~m} /$ tahun, $0.87 \mathrm{~m} /$ tahun dan $0.72 \mathrm{~m} / \operatorname{tahun}$ dan $1.72 \mathrm{~m} / \mathrm{tahun}$ dan 0.97 $\mathrm{m} /$ tahun. Rata-rata tinggi tanaman kenari (Canarium ambonensis) juga meningkat setiap tahunnya. Hal ini menunjukkan bahwa

\section{Hubungan PH Tanah terhadap Riap Pertumbuhan}

Dari analisa statistik menggunakan persamaan regresi linier diperoleh hubungan
Tanaman kenari (Canarium ambonensis) tingginya meningkat setiap tahun. Ruas yang memanjang sebagai ciri dari pertambahan tinggi tanaman merupakan akibat meningkatnya jumlah sel dan meluasnya sel serta nitrogen dan air yang diperlukan dalam jumlah yang banyak sebagai faktor pendukung vegetatif yang sangat cepat.

Cahaya pun merupakan faktor pendukung yang berpengaruh terhadap tinggi tanaman yang mana pucuk bertambah akibat cahaya melalui intensitas, kualitas dan lama penyinaran dari cahaya itu sendiri.

$\mathrm{pH}$ tanah terhadap pertumbuhan tanaman kenari (Canarium ambonensis) dalam hal ini riap diameter dan tinggi yang dapat dilihat pada Tabel 5 di bawah ini.

Tabel 5 Persamaan Regresi pH Tanah dengan Riap Pertumbuhan Tanaman Kenari (Canarium ambonensis)

Riap Persamaan Regresi $\quad r \quad r^{2}$




\begin{tabular}{cccc}
\hline Diameter & $\mathrm{y}=3.260-0.3034 x$ & $\mathrm{y}=0.1648$ & $\mathrm{y}=0.0271$ \\
Tinggi & $\mathrm{y}=2.7789-0.2493 \mathrm{x}$ & $\mathrm{y}=0.1745$ & $\mathrm{y}=0.0304$ \\
\hline
\end{tabular}

Sumber : Data Penelitian 2017

$\mathrm{y}=$ Riap tanaman Kenari

(Canarium ambonensis); $\mathrm{r}=$ Koefesien

Korelasi; $\mathrm{r}^{2}=$ Koefesien Determinasi

Adapun interpretasi koefisien

korelasi nilai $\mathrm{r}$ untuk memastikan hubungan

antar variabel dapat dilihat pada Tabel .6

Tabel 6. Interpretasi Koefisien Korelasi Nilai $r$

\begin{tabular}{cc}
\hline Interval Koefisien & Tingkat Hubungan \\
\hline $0.80-1.000$ & Sangat Kuat \\
$0.60-0.799$ & Kuat \\
$0.40-0.599$ & Cukup Kuat \\
$0.20-0.399$ & Rendah \\
$0.00-0.199$ & Sangat Rendah \\
\hline
\end{tabular}

Sumber: Sugiyono (2008:183)

Berdasarkan nilai koefisien korelasi diameter pada Tabel 5 yaitu 0.1648 dan koefisien korelasi tinggi 0.1745 , maka berdasarkan Tabel 6 dapat ditentukan bahwa hubungan $\mathrm{pH}$ dengan riap pertumbuhan tanaman kenari (Canarium ambonensis) termasuk kategori sangat rendah dengan nilai F hitung $2.73<\mathrm{F}$ tabel $3.94(\alpha=0.05)$ dan $<6.90(\alpha=0.01)$ yang artinya $\mathrm{H}_{0}$ diterima, hubungan $\mathrm{pH}$ tanah tidak berbeda nyata dengan riap pertumbuhan tanaman kenari (Canarium ambonensis). $\mathrm{pH}$ tanah hanya memberikan kontribusi $2.71 \%$ riap diameter dan $3.04 \%$ riap tinggi jadi $\mathrm{pH}$ tanah bukan hanya faktor yang mempengaruhi tanaman kenari (Canarium ambonensis).

pH tanah pada suatu tanaman perlu diketahui untuk mengetahui mudah atau tidaknya unsur hara yang diserap oleh tanaman itu sendiri. Tanaman umumnya tumbuh normal pada tanah yang netral dengan kisaran $\mathrm{pH}$ antara 6-7. Pada kisaran $\mathrm{pH}$ tersebut umumnya unsur hara mudah diserap oleh tanaman dan mudah larut dalam air. Semakin kecil nilai suatu $\mathrm{pH}$ tanah maka tanah tersebut semakin asam, sedangkan sebaliknya bila nilai suatu $\mathrm{pH}$ makin besar, maka tanah tersebut semakin bersifat basa.

Kondisi $\mathrm{pH}$ tanah juga menentukan perkembangan mikroorganisme dalam tanah. Pada pH 5,5 - 7 jamur (mikoriza) dan bakteri pengurai bahan organik yang baik bagi tanaman termasuk tanaman kenari (Canarium ambonensis). (Anonim, 2009).

Dari hasil penelitian, $\mathrm{pH}$ tanah pada lokasi penelitian tahun 2016 dengan kisaran 5.2 - 5.5 dengan rata-rata 5.4 (Majapahit, 2016) dan termasuk kategori masam sedangkan pada penelitian tahun 2017 pH tanah pada lokasi penelitian dengan kisaran 5.0 - 6.2 dengan rata-rata $\mathrm{pH} 5.6$ yang menunjukkan bahwa $\mathrm{pH}$ tanah pada lokasi penelitian termasuk kategori agak masam. $\mathrm{pH}$ tanah pada tanaman kenari (Canarium ambonensis) memiliki kontribusi yang tidak terlalu tinggi terhadap pengaruh pertumbuhan tanaman kenari (Canarium ambonensis) itu sendiri sehingga selain $\mathrm{pH}$ tanah, faktor lain 
tetap menjadi faktor pendukung untuk ambonensis).

pertumbuhan tanaman kenari (Canarium

\section{Hubungan Kelembaban Tanah terhadap Riap Pertumbuhan}

Dari analisa statistik menggunakan persamaan regresi linier diperoleh hubungan kelembaban tanah terhadap pertumbuhan tanaman kenari (Canarium ambonensis) dalam hal ini riap diameter dan tinggi yang dapat dilihat pada Tabel 7 berikut.

Tabel 7. Persamaan Regresi Kelembaban Tanah dengan Riap Pertumbuhan Tanaman Kenari (Canarium ambonensis)

\begin{tabular}{cccc}
\hline Riap & Persamaan Regresi & $\mathrm{r}$ & $\mathrm{r}^{2}$ \\
\hline Diameter & $\mathrm{y}=1.0136+0.0120 \mathrm{x}$ & $\mathrm{y}=0.157$ & $\mathrm{y}=0.0247$ \\
Tinggi & $\mathrm{y}=0.8682+0.0113 \mathrm{x}$ & $\mathrm{y}=0.1911$ & $\mathrm{y}=0.0365$ \\
\hline
\end{tabular}

Sumber : Data Penelitian 2017

$\mathrm{y}=$ Riap tanaman Kenari

(Canarium ambonensis); $\mathrm{r}=$ Koefesien

Korelasi; $r^{2}=$ Koefesien Determinasi

Berdasarkan nilai koefisien korelasi diameter pada Tabel 7 yaitu 0.157 dan koefisien korelasi tinggi 0.1911, maka berdasarkan Tabel 6 dapat ditentukan bahwa hubungan kelembaban tanah dengan riap pertumbuhan tanaman kenari (Canarium ambonensis) termasuk kategori sangat rendah dengan nilai $\mathrm{F}$ hitung $2.49<\mathrm{F}$ tabel 3.94 $(\alpha=0.05)$ dan $<6.90(\alpha=0.01)$ yang artinya $\mathrm{H}_{0}$ diterima, hubungan kelembaban tanah tidak berbeda nyata dengan riap pertumbuhan tanaman kenari (Canarium ambonensis). Kelembaban tanah hanya memberikan kontribusi $2.47 \%$ riap diameter dan 3.65\% riap tinggi jadi kelembaban tanah bukan hanya faktor yang mempengaruhi tanaman kenari (Canarium ambonensis).

Fungsi utama dari kelembaban tanah adalah mengontrol pembagian air hujan yang turun ke bumi menjadi run off ataupun

\section{KESIMPULAN}

Pertumbuhan tanaman Kenari $(C$. ambonensis) di Demplot Sumber Benih Desa Hatusua, Kecamatan Kairatu Kabupaten

infiltrasi. Kelembaban dan suhu sangat mempengaruhi proses pertumbuhan tanaman. Kelembaban tanah yang rendah akan berpengaruh terhadap menurunya jasad yang berada di dalam tanah itu sendiri. Apabila hal itu terjadi maka akan mempengaruhi prosesproses kimiawi dan aktivitas jasad-jasad yang dapat merombak unsur hara dalam tanah yang merupakan asupan yang penting bagi proses pertumbuhan pada tanaman. (Sutejo, 1987).

Pada penelitian sebelumnya tahun 2016, kisaran kelembaban tanah mencapai 31-35 \% dengan rata-rata kelembaban tanah pada tanaman kenari (Canarium ambonensis) 31\% (Majapahit, 2016). Sedangkan hasil penelitian, pada tahun 2017 dengan kisaran kelembaban tanah pada tanaman kenari (Canarium ambonensis) 27.5-65\% diperoleh kelembaban tanah dengan rata-rata $45,8 \%$.

Seram Bagian Barat sangat baik dengan Riap Tahunan Berjalan (CAI) diameter sebesar $2.26 \mathrm{~cm} /$ tanaman/tahun dan Riap Rata-Rata Tahunan (MAI) diameter yaitu 1.41 cm/tanaman/tahun, sedangkan Riap Tahunan 
Berjalan (CAI) tinggi sebesar 1.72 m/tanaman/tahun dan Riap Rata-Rata Tahunan (MAI) tinggi yaitu 0.97 $\mathrm{m} /$ tanaman/tahun. $\mathrm{PH}$ tanah dengan riap pertumbuhan tanaman Kenari $(C$. ambonensis) adalah sangat rendah dengan nilai F hitung $2.73<\mathrm{F}$ tabel $3.94(\alpha=0.05)$ dan $<6.90(\alpha=0.01)$ yang artinya $\mathrm{H}_{0}$ diterima, hubungan $\mathrm{pH}$ tanah tidak berbeda nyata dengan riap pertumbuhan tanaman kenari (Canarium ambonensis). $\mathrm{pH}$ tanah memberikan kontribusi hanya $2.71 \%$ riap

\section{DAFTAR PUSTAKA}

Aak, 1983, Dasar-Dasar Bercocok Tanam, kanisus, Yogyakarta.

Anonim, 2009. Tanaman Obat Indonesia.

Bejo Slamet, S.Hut, M.Si, 2008. Iklim Mikro Bagi Anakan Tegakan Hutan. USU Repository.

Davis L.S and Johnson K.N, 1987. Fores Management .Third Edition.

Dodo, 2005. Pengaruh Media Semai Dalam Peningkatan Produksi Bibit Kenari.

Departemen Kehutanan, 1989. Pedoman Pengelolaan Hutan Rakyat Dirjen Reboisasi dan Rehabilitasi Lahan, Departemen Kehutanan.

G.S.Suhartati Djarkai, 2017. Teknologi Pengolahan Minyak Kenari. Tropical Plant Curriculum Project Sam Ratulangi University. https://kajianpertanian.wordpress.co m/pengaruh-kelembaban-udaraterhadap-tanaman/ di akses pertanggal 8 maret 2017.

Golley, F. B. 1983. Tropical Rain Forest Ecosystem, Structure and Function. diameter dan $3.04 \%$ riap tinggi. Demikian juga hubungan kelembaban tanah dengan riap pertumbuhan tanaman Kenari $(C$. ambonensis) adalah sangat rendah dengan nilai F hitung $2.49<\mathrm{F}$ tabel $3.94(\alpha=0.05)$ dan $<6.90(\alpha=0.01)$ yang artinya $\mathrm{H}_{0}$ diterima, hubungan kelembaban tanah tidak berbeda nyata dengan riap pertumbuhan tanaman Kenari (C. ambonensis). $\mathrm{pH}$ tanah memberikan kontribusi hanya $2.47 \%$ riap diameter dan $3.65 \%$ riap tinggi.

Elsevier Scientific Publishing Company. New York.

Junaidi, W. 2009. Faktor-Faktor yang Mempengaruhi Pertumbuhan Tanaman

Kennedy, J and W.Clarke, 2004. Cultivated Landscapes of the Southwest Pasific. Resource Management in AsiaPasific, Canberra.

Leenhout, P.W., 1959. Revision of the the Burseraceae of the Malaysian area in woder sense. Canarium Stickm. Blumea.

Larcher, W., 1975. Physiological Plant Ecologi. Springer Verlag., Berlin Heidelberg, New York.

Lukmanto, 2015. Uji aktivitas antioksida dan penetapan kadar flavonoid total ekstrak dan fraksi daun kenari (Canarium indicum L.), Fakultas Farmasi Universitas Jember.

Majapahit, J.2016. Study Perkembangan Tanaman Kenari ( Canarium Ambonensis ) Di Desa Hatusua Kecamatan Kairatu Kabupaten Seram Bagian Barat.

Marsono, 1987. Prinsip-prinsip silvikultur Terjemahan Theodore W.Daniel, 
John A

Helms. Universitas

Gadjah Mada Press. Yogyakarta.

Munawaroh, E. dan Roemantyo. 1992. Beberapa Aspek Etnobotani Kenari (Canarium sp) Studi Kasus Kebun Raya Bogor. http://elib.pdii.lipi.go.id/katalok/inde x.php/searchkatalog/downloadDatab

Oldeman, L.R., 1984. Upland rice growing environment. Method for characterization and zonation in Asia. An Overview of Upland Rice Research. IRRI, Los Banos, Philippines.

Permatasari A. Dewi dan T. Nurhidayati. 2014. Pengaruh Inokulan Bakteri Penambat Nitrogen, Bakteri Pelarut Fosfat dan Mikoriza Asal Desa Condro, Lumajang, Jawa Timur terhadap Pertumbuhan Tanaman Cabai Rawit.

Rohaini, K. 2012. Pengaruh Konsentrasi Dan Lama Perendaman Dalam Air Kelapa Muda Terhadap Perkecambahan Biji Kenari (Canarium Indicum L.). Jurusan Biologi Fakultas Sains Dan Teknologi Universitas Islam Negeri Maulana Malik Ibrahim Malang.

Sui, L. , F. Zee, R.M. Manshardt, Mallikarjuna, and K. Aradhya, 1997. Enzyme polymorphisms in Canarium. Scientia Horticulture.

Sutejo, M.M. 1987. Pupuk dan Cara Pemupukan. Rineka Cipta. Jakarta..
Spittlehouse, D. L and R. J. Stathers. 1990. Seedling Microclimate. Land Management Report 65. Ministry of Forest. British Columbia. Canada.

Spur 1952, Forest inventory The Ronald Press New

Santoso, M., 1984. Stasiun Meterologi Pertanian dan Beberapa Cara Pengolahan Data Iklim. Fakultas kehutanan IPB, Bogor.

Sofyan, A. dkk.2012. Demplot Sumber Benih Unggulan Lokal

Thomson, J. Lex A and Evans, Barry. 2006. Canarium indicum var. indicum and harvery (Canarium nut). www.traditionaltree.org.

Tania, N, Astina dan S. Budi. 2012. Pengaruh Pemberian Pupuk Hayati Terhadap Pertumbuhan dan Hasil Jagung Semi Pada Tanah Podsolik Merah Kuning.

Yen, D.E., 1994. Melanesian Arboriculture: Historical perspective with emphasis on genus Canarium in South Pacific Indigenous Nuts. Edited by Steven, M.L., R.M. Bourke, and B.R. Evans. Proceedings of a workshop, 31 October - 4 November, Vanuatu.

Weaver, J.E., and F. E. Clement. 1980. Plant Ecology. Tata McGraw Hill Company Limitted 